\title{
Pemberantasan Terorisme dalam Kaitannya dengan Penyelundupan Obat Terlarang, Senjata dan Pencucian Uang di Kawasan Asia
}

\author{
Jawahir Thontowi
}

\begin{abstract}
The effort of eliminating the terrorism is not only based to the merely law approach but it should be up to the restrain of support element. The support element here means that it could be put into action for narcotics, guns smuggling and money laundrying. Here it would therefore be eraborated the correlation among the three support elements to the effort of eliminating terrorism at Asia region.
\end{abstract}

\section{Pendahuluan}

Kehadiran hukum internasional dan nasional bagi kejahatan terorisme masih terus dipertanyakan. Situasi ini menandakan kejahatan teror merupakan kejahatan luar biasa (extra-ordinary crime) atau juga kejahatan berat kemanusiaan (crime againts humanity), tidak mungkin dapat dicegah dengan hanya mengandalkan pendekatan hukum. Tragedi teror bom di Bali 12 Oktober 2002 telah meluiluh lantakan gedung-gedung dan ratusan korban manusia akibat ulah teroris. Sebagaimana halnya tragedi 11 September 2001, pengeboman WTC di New York juga mengindikasikan suatu kejahatan yang bergengsi dan terlalu mahal biaya sosialnya.

Secara konseptual teror dan terorisme yaitu suatu tindakan atau perbuatan yang dilakukan oleh manusia, baik secara individual maupun secara kolektif, yang menimbulkan rasa . takut dan kensakan atau kehancuran secara fisik dan kemanusiaan dengan tujuan atau motif memperoleh suatu kepentingan politik, ekonomi, ideologis, dengan menggunakan kekerasan, yang dilakukan dalam masa damai.

Dalam prakteknya ada beberapa hal yang hendaknya dicermati. Pertama, teror dan terorisme dapat diwujudkan dalam bentuk kejahatan konvesional yang dilakukan oleh penjahat profesional (conventional terorism). Kedua, kejahatan yang dilakukan oleh aktor negara terhadap warga negaranya (state. terorism) seperti negara-negara yang diktator, facisme, leninisme dan juga autoritarianisme. Ketiga, negara-negara yang terlibat dalam upaya mendukung menyembunyikan para pelaku teror (supporting state of terorism). ${ }^{1}$

1 Bandingkan dengan pandangan Jessica Stern, The Ultimate Terrorists (London: Havard University Press, 1999), hlm 13. 
Bentuk kejahatan seperti penyeiundupan senjata, obat-obat terlarang dan pencucian uang merupakan tiga faktor yang dapat terkait dengan kejahatan terorisme. Karena itu model penanggulangannya tidak mungkin hanya dengan hukum, melainkan juga harus menyentuh wilayah-wilayah yang biasa dipergunakan oieh penegak hukum dapat menginvestigasi kejahatan lintas negara. Karena itu, hukum yang terkait dengan senjata api, obat terlarang, keimigrasian, dan tempat seperti pelabuhan darat dan udara, bea cukai, juga sistem pemberantasan yang dilakukan secara terpadu sangat diperlukan oleh aparat pemerintah dan penegak hukum. Kompleksitas kejahatan terorisme secara komprehensif hanya mungkin dapat dikendalikan bilamana unsur pendukung dapat diberantas dan faktor ketidak adilan struktural juga dapat ditegakkan.

Menurut Boaz Ganor ada tiga tahap yang perlu dilalui dalam pemberantasan kejahatan terorisme. Pertama, perundang-undangan dan sistem pemidanaan. Hukum yang diundangkan untuk menyediakan kepastian bagi aparat penegak hukum kejahatan penyelundupan senjata, obat terlarang dan pencucian uang. Kedua, kerjasama internasional. Model kerjasama yang diciptakan bukán hanya untuk memperkuat hubungan termasuk tukar menukar informasi intelijen, melainkan juga dituntut untuk mengimplementasikan konvensi intermasional. Di lapangan juga penlu peningkatan kemampuan aparat penegak hukum termasuk di dalamnya pengawasan terhadap pintu gerbang imigrasi, pelabuhan-pelabuhan udara dan darat. Ketiga, gerakan aksi terbuka. Suatu upaya pemerintah yang dibuat untuk menyebariuaskan berbagai bentuk kegiatan teror dan sejenisnya melalui kampanye, penyebarluasan informasi dengan media massa dan elektronik. ${ }^{2}$ Dalam tulisan ini, model pertama dan kedua akan dielaborasi di bawah ini.

\section{Kejahatan Lintas Negara di ASEAN}

Kejahatan terorisme, penyelundupan obat terlarang dan senjata, juga pencucian uang tidak mungkin efektif hanya dengan mengandalkan instrumen hukum. Sifat kejahatannya yang lintas negara (transnational crime) dan juga kejahatan teror acapkali terkait dengan penyelundupan obat terlarang, senjata dan pencucian uang. Ketiga faktor ini sebenamya telah menjadi pola kejahatan terorisme lintas negara. Menurut studi yang dilakukan oleh Joan Honwana dan Guy Lamb dari Centre For Conflict Resolution University of Cape Town, South Africa, terhadap senjata genggam, situasi berbalik dengan begitu besarnya permintaan yang juga menimbulkari pertentangan di negara-negarà ketiga, seperti Afrika, Amerika Serikat, Inggris, Prancis, dan banyak negara Eropa Timur tergolong negara pensuplai senjata untuk negara ketiga. ${ }^{3}$

Tidak seperti persoalan obat terlarang, penjualan senjata genggam adalah tidak dilarang, dalam batas yang digariskan resolusi

${ }^{2}$ Lihat Boaz Ganor, Defining Terrorism: Is One Mans Terrrorist Another Mans Freedom Fighter? (ICT. Executive Director. October 7th, 2001).

${ }^{3}$ Joan Howana \& Gay Lamb, Small Arms Proliferation and Drug, Trafficking in South Africa (Centre For Conflict Resolution Cape Town: University of Cape Town South Africa, 1998), him 154. 
PBB dan Undang-Undang Nasional. Secara lebih tegas dikatakan bahwa the phenomena of small arms proliferation and drug trafficking are conceptualized, and the toal of the trade, namely small arms and drig are defined. In basic.terms, small arms are perceived to be that ranged of manufactured weapon designed for personel use, such as pistols, grenades and automatic weapons. ${ }^{4}$

Intinya menegaskan bahwa penyebaran senjata genggam dan penyelundupan obat terlarang, baik untuk dijual maupun dipergunakan untuk kepertuan pribadi telah menjadi praktek yang sebagian masyarakat tertentu, sehingga pemberantasannya tidak begitu mudah, oleh karena sifat dari kejahatan lintas negara terorganisir.

Kejahatan terorganisasi yang memiliki sifat transnasional merupakan suatu aktivitas kejahatan yang dilakukan oleh aktor-aktor profesional, terlatih dan memiliki keberanian dan loyalitas yang tinggi terhadap kelompok atau jaringan pasar intemasional dan nasional. Aktivitas kejahatan terorganisir dapat berlangsung dengan kokoh, bahkan sukar disentuh hukum. Jurisdiksi geografis tidak mudah lagi diawasi atas nama kedaulatan negara sebab mereka bukan hanya memiliki jaringan organisasi yang rapi, akan tetapi juga terkadang mendapat bantuan secara rahasia dari oknum pejabat pemerintah atau penegak hukum. Hal ini terutama terjadi di negara-negara yang pemerintahnya tergolong tidak bersih dari praktek korupsi dan kolusi (unclean govemment). ${ }^{5}$

Studi semacam ini masih belum banyak dilakukan. James H. Mittelman menyebutkan bahwa kejahatan terorganisir, dalam kebanyakan literatur Amerika Serikat, tergambar dalam studi kriminologi, ilmu politik, dan lebih luas lagi penelitian dalam wilayah administrasi kepolisian, agen-agen intelijen pemerintah, organisasi-organisasi internasional, dan lembaga studi dan pemikir yang berupaya untuk memberantas terorisme dan berbagai bentuk tindakan-tindakan yang melawan hukum. ${ }^{6}$

Dick Hobbs menyebutkan ciri utama dari kejahatan terorganisir, yaitu selain dilakukan oleh aktor penjahat profesional, memiliki tempat transaksi atau pasar yang menyebar (market place), dibangun oleh penjahatpenjahat profesional dengan sistem operasi dan pagar perlindungan sangat kuat. Pagar perlindungan mereka antara lain selain fungsi kekuatan organisasi terstruktur yaitu penjual (sellers) dan pembeli (buyer) barang-barang yang dicuri tergolong transaksi jual beli yang diatur sangat kaku dan berbahaya. ${ }^{7}$

Implikasi kejahatan transnasional tersebut, dewasa ini tidak mudah dicegah dan ditindak. Salah satu penyebabnya karena ada kecenderungari semakin tipisnya dan problematik perbedaan batas antara perbuatan yang legal dan ilegal, termasuk juga domein antara negara dan masyarakat.

\section{${ }^{4} /$ bid., hlm 155.}

${ }^{5}$ Penjelasan lanjut bisa dilihat Jawahir Thontowi, Hukum Intemasional di Indonesia: Dinamika dan Implementasinya dalam Beberapa Kasus Kemanusjaan (Yogyakarta: Madyan Press, 2002), hlm 83.

${ }^{6}$ Isu mengenai kejahatan terorganisir global bisa dicermati tulisan James $\mathrm{H}$. Mittelman, The Globalization Syndrome: Transformation \& Resistance (New Jersey: Priceton University Press, 2000), hlm 202.

${ }^{7}$ Penjelasan lebih detil lihat Dick Hobb, "Professional and Organized Crime in Britain" in Mike Maguire etc.(ed.), The Oxford Handbook of Criminology (Oxford: Clarendon Press, 1994), hlm 444. 
Dalam konteks apa yang menjadi. motif globalissasi terkait dèngan beberapa kebutuhan dasar masyarakat internasional. James $\mathrm{N}$ Rosenau, melihat antara hubungan intemasional ditentukan oleh aktivitas-aktivitas yang terdin dari enam komponen, yaitu barang-barang dan jasa, orang-orang, ide dan informasi, uang, orientasi nilai, dan pola tingkah laku praktis. Dari keenam faktor, barang dan jasa tidak dapat diawasi secara jeli oleh karena jumlah dan kualitasnya begitu luar biasa. Tentu saja jumlah barang dan jasa juga telah menekan gelombang pengirimannya yang kemudian memaksa menjadi suatu proses evolusi pasar global. ${ }^{8}$ Dengan kata lain, kejahatan transnasional yang terorganisir benar-benar mengancam negara dalam keseluruhan dimensinya.

Akibat akselerasi global dalam jual beli senjata, pemasaran material nuklir, prospek pengiriman nuklir secara terselubung, sangat mempenganuhi situasi perdamaian masyarakat internasional. Sebagaimana terlihat dari pasangan antara negara-negara Amerika Serikat, Soviet, Iran, Irak, dan Korea Utara. Kesulitan pemberantasan kejahatan terorganisir internasional seperti terorisme, penyelundupan senjata, pencucian uang yaitu karena adanya hubungan kerjasama yang rapi selain antara penjahat profesional mereka sendiri dengan oknum-oknum pejabat, terutama melalui analisis segitiga kekuatan teritorial. Ada beberapa model kejahatan lintas negara yang bisa dijadikan pertimbangan dalam menentukan model kerjasama penanggulangan.

Kejahatan terorganisir berlangsung antara Nigeria dan Myanmạr. Misalnya, model pertama, Washington memutuskan hubungan bantuan kerjasama kepada Nigeria dan Myanmar karena kedua negara telah melanggar perjanjian bilateral. Warga negara kedua negara terlibat dalam kejahatan narkotik dengan pencucian uang. Sama halnya dengan kejahatan terorganisir yang dilakukan secara internasional terkait dengan timbulnya peperangan lokal dan nasional. Negaranegara seperti, Sri Lanka, Pakistan, Libanon banyak terlibat dengan pertikaian masal baik karena sentimen suku, agama, maupun golongan. Dalam pembiayaan peperangan, mereka umumnya acapkali terkait dengan penyelundupan obat-obat terlarang (drug trafficking) sebagai sumber pendanaan bagi kekerasan dan teror.

Model kedua, pemberantasan kejahatan terorganisir terkait dengan penggunaan genggeng kejahatan dalam proses politik sipil dan pemerintahan. Nielson Mandella yang terpilih sebagai presiden Afrika Selatan tidak lepas dari peran dan bantuan tangan-tangan pejahatan profesional. Konflik antara geng yang pernah mendukung Nieison Mandella dan kelompok PAGAD (People Against Gansterism And Drugs) memperlihatkan adanya hubungan korelatif. Memang PAGAD berhasil memberantas berbagai kejahatan dan mafia gangster serta obat-obat terlarang, akan tetapi dalam kenyataan pemerintah Afika Selatan tidak memihak ke PAGAD. Konflik PAGAD yang anggotanya didominasi oleh Muslim dan kelompok gangster, dan pengedar obat-obatan serta elemen tentara dengan masyarakat sipil, tidak mampu memelihara stabilitas keamanannya karena negara tidak

${ }^{8}$ James N. Rosenau, Along The. Domestic - Foreign Frontier: Exploring Governance in a Turbulent World (Cambridge: Cambridge. Studies in Intemational Relations, Cambridge University Press, 1997), hlm 87. 
memiliki kapasitas untuk melakukan tindakan pencegahan dan penangkapan. ${ }^{9}$

Model ketiga, praktek kejahatan TOC tersebut, pada dasarnya telah mengancam negara-negara, dan warga negaranya. TOC telah menjadi ancaman serius karena mengancam kesejahteraan dan keamanan warga negara (human security). Misalnya, di Kolombia pernah tercatat pembunuhan sebesar 28000 jiwa pertahun, $40 \%$ motif pembunuhan terkait dengan narkotik. 'Situasi seperti itu menimbulkan ancaman serius terhadap keamanan dan keselamatan jiwa masyarakat. Lebih jauh UNDP mengidentifikasi konsep ancaman keamanan (human security) yaitu keamanan ekonomi (economic security), ancaman terhadap makanan dan kesehatan, lingkungan, keamanan jiwa, masyarakat dan keamanan politik. ${ }^{10}$

Model keempat, kejahatan terorganisir lintas negara sejauh ini terkait dengan negaranegara yang lemah (weak state) dalam penegakan hukum dan dalam situasi merealisasikan demokrasi. Kegagalan melakukan pemberantasan kejahatan terorganisir tersebut disebabkan oleh jasa-jasa oknum pejabat yang korup. Situasi yang sama juga terjadi karena ada hubungan antara kebebasan perdagangan (NAFTA), yang unequal, sehingga pengapalan dan pengangkutan heroin dari Meksiko ke Amerika Serikat, terus berlangsung. Partai Nasional Prancis, yang menentang kebijakan persetujuan Uni Eropa yang membebaskan warga negara-negara dari pengawasan pabean dalam kaitannya dengan memperiunak hubungan antara batas negara."

Kebijakan itu terbukti telah mempengaruhi secara fundamental situasi kemanan yang bertolak belakang dengan tendensi global. Upaya untuk memperiunak pengawasan terhadap masuknya orang asing di kantor imigrasi juga ancaman nyata bagi keamanan dalam negeri. Menurut Philip Yusario isu TOC merupakan sebuah kasus yang mempertemukan kedua pandangan tersebut. Bagi negara dengan wilayah iuas dan memiliki perbatasan terbuka tentunya TOC beroperasi secara lintas batas dan menjadi ancaman riil. TOC telah menjadi ancaman riil kelangsungan keamanan negara dan juga menjadi ancaman langsung bagi kesejahteraan individu dan masyarakat. ${ }^{12}$

Dalam hubungan dengan itu, ancaman TOC tersebut juga terjadi di negara-negara ASEAN, Robert Johnston misalnya menegaskan bahwa TOC, yang bentuknya bisa berupa penyelundupan dan perkembangan kelompok gang kejahatan tumbuh di negara-negara yang marginal atau memang miskin. Suatu operasi penyelundupan tidak mungkin dilakukan tanpa adanya bantuan dari penjahat-penjahat yang kuat dan kaya. Terjadinya korupsi di jajaran lembaga adalah merupakan lingkaran yang tidak terelakkan dijajaran pabean dan bea cukai, kepolisian, petugas perpajakan. Situasi ini telah beriangsung bukan saja penyelundupan

"James H. Mittelman and Robert Johnston, "Global Organized Crime", in J. Mittelman The Global Syndrome. Transformation and Resistence (New Jersey: Princeton University Press, 2000), hilm 219.

${ }^{10}$ Philip Yusario, Ibid., hlm 216

${ }^{11}$ Ibid., hlm 216

${ }^{12}$ Lihat Philip Yusario, "Transnational Organizer Crime. Isu dan Permasalahannya", dalam Analisa CSIS. No.Th.XXXI. Tahun 2002, him 48. 
obat terlarang, pembajakan paten, transaksi keuangan yang tidak sah (pencucian uang), dan seluruh aktivitas kejahatan dalam wilayah biru atau pasar gelap.

Segitiga emas kejahatan tersebut terjadi di wilayah perluasan antara Laos, Thailand, dan Myanmar, terutama terjadi ketika perang dingin. Menurut Johnston, eksportir kejahatan TOC tersebut berkembang dari Rusia, China dan Mexico. Peta kejahatan ini juga terihat di sebagian tempat seperti sebagian etnik China di Hongkong, yang menghubungkan dengan produsen heroin - obat terlarang di Myanmar, Amerika Serikat, Eropa Barat, masuk ke wilayah Pasifik. ${ }^{13}$ Peta kejahatan terorganisir lintas negara telah berlangsung di Asia Tenggara seperti pelaku kejahatan dari Afrika, Bangkok, Denpasar sebagai tempat transit sebelum mereka tiba di Australia.

Untuk menempatkan Indonesia dalam model TOC di atas tidaklah sulit. Pertama, Indonesia negara kepulauan yang luas dengan situasi pengawasan yang dilakukan oleh petugas-petugas pelabuhan hanya bertanggung jawab terhadap aspek perusahaan pengusahaan pelabuhan di Indonesia. PT. Pelindo dan juga angkatan laut kurang memadai. Indonesia saat ini sedang berada dalam situasi krisis di mana peran pemerintah dan penegak hukum sangat lemah, sehingga berbagai bentuk kejahatan dan perbuatan yang mengancam keamanan nasional tidak bisa ditegakkan. Kedua, Indonesia tergolong negara yang memprihatinkan. Oleh karena Korupsi, Kolusi dan Nepotisme (KKN) terus berlangsung, dan sampai saat ini tidak mampu mencari jalan keluarnya.
Meningkatnya imigran gelap mengancam integritas bangsa. Disebabkan oleh desakan ekonomi, Tenaga Kerja Indonesia (TKI) ilegal semakin tidak bisa dibendung. Dalam bulan Juli 2002 tercatat 100 ribu TKl ilegal, kemudian Juli 2002 tercatat sekitar 380 ribu TKI ilegal yang kemudian menjadi bencana Nunukan. Akibatnya, hubungan kedua negara MalaysiaIndonesia terancam retak. Sebaliknya, telah tercatat sekitar 4000 imigran gelap pada 4 November 2001. Penyelundupan manusia termasuk pendapatan ketiga besar, sebab setiap orang bisa membayar US $\$ 400$. TOC penyelundupan manusia sangat sulit sebab terlibat banyak peran, dalam konteks ini negara-negara terlibat China ke Malaysia Indonesia - menuju ke Australia. ${ }^{14}$

Ketiga, kejahatan TOC penyelundupan obat terlarang (drug trafficking) tidak saja dibuktikan melalui derasnya alur kejahatan di dalam negeri, tetapi juga ke luar negeri. Segi lain yang terkait dengan kekerasan yaitu peta persoalan konflik lokal yang terjadi seperti Gerakan Aceh Merdeka (GAM) di Aceh, Papua Merdeka di Papua, Poso dan Ambon menupakan wilayah yang menyuburkan tumbuhnya pasar gelap bagi jual beli senjata, obat terlarang, dan juga pencucian uang. Konspirasi internasional yang secara ideologis memiliki komitmen atas gagasan self-determination membuka ruang bagi mereka untuk melakukan transaksi ilegal.

Hukum tersebut secara domestik telah cukup memadai jika persoalan narkotik tersebut urusan nasional. Atas dasar fakta narkotik sebagai bagian dari TOC, maka masyarakat dunia sepakat untuk mengesahkan Konvensi

\footnotetext{
${ }^{13}$ /bid., hlm 213.

${ }^{14}$ Philip Yusario, Ibid., hlm 490. Lihatjuga Jawahir Thontowj, "TKI di Nunukan", harian Kedaulatan Rakyat, 15 Agustus 2002.
} 
PBB mengenai lalu lintas perdagangan obat narkotika dan bahan obat psykotropika (Hasil putusan Rapat Pleno PBB No. 6, 19 Desember 1988). Konsekuensi lahirnya konvensi ini bukan sekedar setiap negara diwajibkan meratifikasinya, melainkan juga kewajiban bagi setiap negara anggota untuk melakukan pemberantasan melalui peningkatan kerjasama multilateral secara kongknitterpadu. Menurut Dinas Penerangan Polri kasus narkoba yang disidik 3.122 kasus, dengan 4.402 tersangka. Perlaku Warga Negara Indonesia (WNi) yaitu 4.334 dan sekitar 268 Warga Negara Asing (WNA). ${ }^{15}$

Berdasarkan fenomena global di atas, maka upaya kerjasama, baik bilateral maupun multilateral harus dilakukan segera. Tidak saja setiap negara harus memiliki ketentuan hukum seperti penyelundupan senjata, dan obat terlarang, dan pencucian uang, melainkan juga perlu péngawasan keimigrasian, dan masuknya pengungsi atau imigran gelap, serta meningkatkan kerjasama dalam memantau tempat yang mudah dijadikan penyelundupan.

\section{Kerjasama Multilateral ASEAN dan Tantangannya}

Ketika program-program terbuka melaluj kampanye Anti Teroris, Anti Drug, Weapon dan Money Loundering disosialisasikan kepada masyarakat, maka tuntutan lain yang pasti harus dipenuhi adalah pejabat-pejabat pemerintah sepantasnya menjadi teladan yang baik. Syarat tegaknya pemerintah yang bersih dan baik sebenamyaterkait dengan kemampuan yang kredibel dalam kaitannya dengan penerapan hukum di lapangan.

Masalah utama mengenai kerjasama
Kejahatan Lintas Negara (KLN) telah dibahas sejak tahun 1997, melalui deklarasi ASEAN mengenai Transnational Crime oleh MenteriMenteri Dalam Negeri. Dua tahun berikutnya, yaitu Juni 1997, agenda lebih operasional terkait dengan The ASEAN Plan of Action to Combat Transnational Crime. Kongkritnya dari kesepakatan itu antara lain, tukar menukar informasi, kerjasama dalam lembaga penegakan hukum, kinerja dan kapasitas training serta kejasama regional. Pembahasan mengenai isu terorisme telah dikembangkan upaya-upaya kongkrit mengenai pemberantasannya satu bulan sejak tragedi 11 September 2001, yaitu tanggal 11 Oktober 2001. Protes dari berbagai negara seperti RI, pemerintah Australia, tidak dihiraukan sebab ketentuan hukum mati menjadi jurisdiksi kedaulatan hukum nasional Malaysia.

Kemudian pada tanggal 17 Mei 2002, dikeluarkan suatu kesepakatan bersama negara-negara ASEAN untuk memberdayakan pejabat tinggi ASEAN menjalankan joint communique, mengenai realisasi Program Kerja Terorisme dalam kaitannya . dengan pelaksanaan rencana kerja pemberantasan Kejahatan Lintas Negara. Dari rencana kerja ASEAN itu, maka pemberantasan terorisme dimaksudkan selain aktor masyarakat, negara dan organisasi, juga elemen-elemen terkait dengan persoalan-persoalan tumbuh subumya gerakan teror. Elemen-elemen tersebut terkait dengan kejatiatan penyelundupan dan penyalah gunaan obat terlarang, senjata dan pencucian uang yang dapat mendukung gerakan terorisme.

\footnotetext{
${ }^{15}$ Lihat tabel 5 No. 9 dalam www.tempo.co.id/hárian/fokus/55/2,1,14,id.html
} 


\section{Penyelundupan Obat Terlarang dan Senjata.}

Perumusan kerjasama yang lebih kongkrit dalam hal penyelundupan obat terlarang dan senjata termasuk persoalan yang sangat vital. Diakui bahwa pemerintah Indonesia telah memiliki peraturan hukum, melalui ratifikasi dua ketentuan hukum internasional, dilengkapi dengan peraturan lainnya. Pertama, pengesahan Convention on Psychotropic Substance 1971 melalui UU No. 8 tahun 1996. Dalam ketentuan tersebut telah diatur secara umum dan sistematis mengenai konsep narkotika sebagai obat (yang bisa disalahgunakan), jenis, pembuatan, penjualan, pengedaran dan berbagai penggunaan termasuk proses impor dan . ekspor. Begitu juga institusi yang memiliki kewenangan melakukan penyidikan. Penyidik Pejabat Pẹgawai Negeri (PPPNS) (pasal 69 ayat 2) dan Penyidik Polri (pasal 71). ${ }^{16}$

Kedua, penyelundupan senjata cukup memprihatinkan dalam kaitannya dengan kejahatan terorisme. Keprihatinan penyelundupan senjata (weapon smugling) bukan sekedar tidak adanya peraturan hukum yang memadai, melainkan karena penyelundupan senjata dianggap terpisah dengan kejahatan lainnya, terutama obat-obat terlarang. Bagaimana mungkin dalam era global UU Danurat No. 12 tahun 1951 akan efektif dalam memberantas kejahatan penyelundupan senjata dan sejenisnya bila dibandingkan dengan fenomena penggunaan senjata yang marak dipergunakan masyarakat. Sangat jauh dari memadai bilamana dibandingkan dengan fenomena di atas. Dinas Penerangan Polri melaporkan 12 peristiwa yang menonjol diAceh, antara lain: penembakan (158 kasus) kontak senjata (94 kasus), penyerangan markas pos Polisi atau TNI ( 96 kasus), penemuan senjata (53 kasus), dan peledakan granat dan bom (204 kasus). Dalam kasus kerusuhan Ambon yang melibatkan masyarakat antara Muslim dan Non-Muslim, senjata-senjata yang dipergunakan tidak terbatas pada senjata genggam dan sejata berat lainnya, melainkan juga penggunaan bahan-bahan peledak seperti granat dan bom. Sama halnya dengan kasus Timor-Timur pasca jajak pendapat, milisi-milisi pro integrasi yang memiliki senjata diperoleh selain melalui penyelundupan, juga pasokan dari oknumoknum tertentu yang tidak setia lagi pada TNI dan Polri. Mereka ini umumnya tergolong oknum yang terkena sanksi indisipliner karena melakukan pelanggaran atau telah terlibat dalam kejahatan. ${ }^{17}$ Anggota Polri yang melanggar antara lain, selama tahun 2000, Polri telah memecat 218 personil mencakup perwira, bintara dan tamtama. Pemecatan dijatuhkan karena mereka terlibat dalam kejahatan narkoba, pembunuhan, penyalah gunaan senjata api, dan pencurian kendaraan bermotor. ${ }^{18}$ Adapun penggunaan senjata liar telah dilaporkan oleh Tim Sapu Jagat tahun 2000 terdapat 108 perkara dan 236 tersangka

${ }^{18}$ Lihat Pasal 78 UU No 8/1996, ancaman pidana matidengan denda 1 miliar.

"Dalam suatu diskusi diceritakan bahwa terdapat beberapa oknum TNI dari Malang yang mensuplai atau menjual senjata terhadap masyarakat di Ambon. Bahkan dalam tulisan Barbara $\mathrm{H}$. Sillar, Droping senjata terhadap kaum pemberontak di Sulawesi Selatan telah menjadi rahasia umum. Ini terjadi karena antara oknum TNi dengan pemberontak lokal memiliki hubungan kekerabatan dan kesamaan suku, selain agama. Lihat/slam, Politics and Tradition in South Sulawesi (New York, Comell University Press, 1977). 
karena terlibat dalam pendistribusian, pengedar, pengguna dan perakit ilegal senjata api, peluru dan serbuk mesiu atau serbuk peluru:

- Menarik untuk diperhatikan tulisan Joao Honwana dan Guy Lamb, yang menyebutkan bahwa dewasa ini ada sekitar 300 pengusaha dan menyebar di sekitar 50 negara yang terlibat dalam pembuatan senjata genggam dan perlengkapan lainya. Pelacakan terhadap penyalahgunaan jual beli senjata gènggam dan berat tidaklah mudah. Pertama, dilihat dari segi sejarah pembuatan senjata telah menjadi tradisi bagi wilayah-wilayah yang acapkali terjadi konflik 'dengan menggunakan kekerasan: Kedua, semula pembuatan senjata genggam tergolong usaha yang tidak dilarang. Oleh karena itu, pembuatan senjata genggam menjadi.produksi domestik yang dapat membantu ekonomi masyarakat. Ketiga, konvensi hukum internasional mengenai penggunaan, pembuatan dan jual beli komoditi senjata umumnya dibuat jika terjadi konflik dengan kekerasan. Misalnya, PBB melarang pengiriman senjata ke Rwanda tahun 1994, sebab negara tersebut telah terlibat dalam praktek genocide, sebagai kejahatan berat. ${ }^{19}$.

Memang ancaman hukuman mati (maksimal) bagi kejahatan senjata api cukup berat dan sekurang-kurangnya 10 tahun telah tersedia. Juga sama halnya dengan sanksi hukuman bagi mereka yang melakukan pelanggaran karena membawa senjata tajam. Di dalam KUHP seperti dalam pasal 500, menegaskan bahwa barang siapa tanpa ijin kepala polisi atau pejabat yang ditunjuk untuk itu, membikin obat ledak, mata peluru, atau. peluru untuk senjata api diancam kurungan paling lama sepuluh hari atau denda paling banyak lima puluh rupiah. Pasal tersebut: tidaklah mungkin dapat dipergunakan untuk memberantas penyelundupan senjata. ${ }^{20}$

Dihadapkan pada situasi internal maupun eksternal, peraturan hukum, tertuang dalam UU Darurat No. 12/1951, tidak responsif dengan praktek penyelundupan lainnya. Tentu saja hal ini terkait dengan Undang-undang Keimigrasian, Bea Cukai dan peran pengawasan di pantai-pantai. Dugaan adanya penyelundupan senjata atau jual beli senjata antara negara yang menjadi pemasok, atau fasilitator telah menjadi rahasia umum. Sebagaimana dilaporkan oleh Kantor Bea Cukai Surabaya, telah menggagalkan penyelundupan senjata api, 5 unit pistol, 1.924 butir amunisi, dan 42 unit perlengkapan senjata lain. ${ }^{21}$

Dugaan senjata dipasok oleh intervensi asing terhadap wilayah konflik cukup beralasan. Misalnya, kapal berbendera Australia tertangkap basah membawa senjata di Teluk Ambon. Dari keterangan yang dihimpun, kapal MV Alfred Nobel berbenidera Australia itu tidak tergolong penyelundup, namun ada dugaan dari sebagian pihak, mengapa kapal Australia itu merapat di wilayah Ambon,

${ }^{18}$ Laporan Dinas Penerangan Polri, dalam www.tempo.co.jd/harian/55/2,1,14, id.html

19 Joan Honwana, op.cit., him 155.

${ }^{20}$ Lihat Moeljatno. KUHP, (Yogyakarta: Bumi Aksara, 1982).

"21"Bea dan Cukai Surabaya Gagalkan Penyelundupan Senjata Api", www.kompas.com/kompas-cetakJ 0207/0207/03daerah/beak/19htm. 
sehingga cukup mencurigakan. ${ }^{22}$ Sama halnya penyelundupan senjata itu, dilakukan terhadap kasus Aceh. Misalnya, pemerintah Thailand telah membongkar penyelundupan senjata yang akan dikirim ke Aceh. Menurut sekretaris Presiden, Wimar Witoelar, bahwa Thailand dalam hal ini sebagai negara yang terbuka dan memungkinkan siapa saja masuk ke negaranya. ${ }^{23}$ Tetapi telah cukup waspada karena pemerintah Thailand telah berhasil menggagalkan penyelundupan senjata.

Tentu saja sebaik apapun peraturan hukum yang dibuat termasuk kerjasama multilateral tidak akan efektif.jika tidak dilengkapi dengan institusi yang memadai. Situasi Indonesia sebagai negara pulau (archipelago state) mengindikasikan kerawanan pulau tidak bisa dihindarkan bila dibandingkan dengan petugas yang tersedia, termasuk TNI Angkatan Laut. ${ }^{24}$ Tuntutan untuk meningkatkan jumlah aparat keamanan dan penegak hukum serta peningkatan kualitas pelayanan.

\section{Kerahasiaan Institusi Bank}

Kerjasama multilateral ASEAN yang perlu ditingkatkan lebih kongkrit yaitu mengenai penanggulangan pencucian uang. Dalam hal ini terdapat dua hal penting yang terkait, yaitu melakukan kerjasama dalam hal mengungkap nasabah yang terlibat dalam kejahatan pencucian uang, dan membuka identitas dan aktivitas nasabah yang bersangkutan. Hal ini perlu oleh karena denyut kejahatan terorganisir secara lintas negara tidak bisa disentuh disebabkan adanya prinsip kerahasiaan Bank (Bank Secrecy). Ketentuan hukum masalah ini telah diatur dalam UU No. 7 Tahun $1992 \mathrm{Jo}$. UU No. 10 Tahun 1998.' Di mana prinsipprinsip umum tentang institusi bank untuk merahasiakan nasabahnya dilindungi.

Dalam dimensi nasional, kehadiran UU No. 15 tahun 2002, 17 April tentang tindak pidana Pencucian uang sangat relevan. Pertama, kehadiran undang-undang tersebut bukan saja dimaksudkan sebagai upaya kongkrit terhadap makin maraknya praktek pencucian uang, uang yang haram lalu dimasukkan ke dalam sistem manajemen keuangan oleh jasa-jasa keuangan (bank). Kedua, merupakan wujud dari komitmen tinggi terhadap TAP No. VIII/MPR/2001 tentang Rekomendasi Arah Kebijakan Pemberantasan dan Pencegahan Korupsi, Kolusi dan Nepotisme.

Secara kelembagaan, UU ini juga mengatur tentang institusi yang memiliki kewenangan untuk melakukan penyelidikan dan pengawasan. PPATK (Pusat Pelaporan dan Analisiṣ Transaksi Keuangan) sama halnya dengan CTR (Currency Transaction Report) dan juga FATF yaitu The Financial Action Task Force yang dibuat oleh negaranegara G7 yang tugasnya selain membuat kebijakan juga mengembangkan tentang cara-cara yang komprehensif mengenai pemberantasan pencucian uang. ${ }^{25}$ Pendekatan juridis tersebut belum berhasil optimal. Kedudukan Indonesia sebagai negara yang terkorup keempat di dunia setelah negara-

${ }^{22}$ Tim Penyidik Independen Nasional (TPIN) Diminta Usut Penyelundupan Senjata di Ambon, harian Republika, 12 Juli 2002.

${ }^{23}$ "Thailand Selidiki Penyelundupan Senjata ke Aceh", uww.tempointeraktif, 15 Mei 2001,

${ }^{24}$ Lihat Perairan Indonesia Bagian Barat Rawan Penyelundupan, Tempo Interaktif, 8 Agustus 2002. 
negara di Asia lainnya menjadi bukti kongkrit.

'Citra Indonesia masih negatif dan kurang serius dalam pemberantasan pencucian uang terlihat pada penilai masyarakat internasional sebagai negara yang tidak Cooperative Countries and Territories. Anehnya meskipun pemerintah RI telah mengeluarkan UU No. 15 Tahun 2002 tentang pencucian uang, negaranegara yang tergolong pada FATF belum mencabut status Indonesia sebagai negara NCCTS. Alasan-alasan mengapa Indonesia b́elum dikeluarkan dari NCCTS, antara lain UU No. 15 Tahun 2002 belum memuat prinsip standar yang disepakati oleh FATF (Financial Action Task Force on Money Loundering) yang antara lain, Pertama, sanksi kolektif bagi negara-negara pelanggar untuk tidak dilayani atau ditutup transaksi dan Loan. Kedua, tidak menerapkan prinsip mengenal nasabah (Know Your Customer), antara lain menerapkan kebijakan identifikasi nasabah, aktivitas bisnis nasabah, pemantauan rekening, dan juga pemantauan terhadap nasabah yang melakukan transaksi tunai sejumlah Rp $500.000 .000,00$. Ketiga, adanya lembaga independen yang berwenang untuk melakukan penyelidikan jika diduga ada nasabah yang melakukan transaksi secara mencurigakan. ${ }^{26}$ . Dilihat dari segi sistem ekonomi, setiap praktek pencucian uang merugikan negara. Pertama, membiarkan masyarakat menikmati "uang haram" berarti mengijinkan Organized Crime yaitu membangun sistem usaha yang ilegal, seperti judi, pacuan kuda, casino, bank gelap, obat terlarang. Kedua, pencucian uang melahirkan kondisi persaingan bisnis yang tidak jujur. Moral bisnis dan ethos kerja bakal menurun, wibawa hukum merosot. Dana besar yang dapat dipergunakan sebagai model produktif hanya dapat tersedot sebagai uang pelicin (penyuapan) secara sarkastik, majalah TEMPO menyingkat DPR sebagai Dewan Persuapan Rakyat. Ketiga, praktek pencucian uang akan melemahkan sistem keuangan masyarakat. Pencucian uang yang tak kalah anehnya, mereka tidak menyimpan uang di Bank, ketika tetapi mereka berlomba-lomba membeli tanah agar uang tidak bisa dilacak. ${ }^{27}$

Sebagai bahan perbandingan bagaimana hukum intemasional mengatur dan melengkapi dengan berbagai parameter operasional yang cukup terpadu. Menurut Michael Levi, upayaupaya yang dilakukan pemerintah di berbagai negara terhadap praktek pencucian uang itu memang tidak terlepas dari strategi global melalui kemampuan perundang-undangan sebagai alat bantu hukum terhadap penyelidikan keuangan dan juga untuk pengendalian kejahatan 'atau penyitaan. Negara-negara sepertiAmerika Serikat yang didukung Australia, Prancis, dan Inggris merupakan negara-negara yang sangat menaruh perhatian terhadap pemberantasan pencucian uang yang dikaitkan dengan penyalahgunaan atau transaksi jual beli obatobat terlarang. Perkembangan pemberantsan pencucian uang yang terkait dengan penyelundupan obat-obat terlarang semakin terasa penting, terutama sejak keluarnya Konvensi Wiena PBB 1988, tentang kekuatan isu obat terlarang dalam budaya politik di

26 Lihat "Indonesia Termasuk Negara Non-Cooperative Dalam Pencegahan Pencucian Uang", Republika on Line. Selasa 9 Juli 2002.

${ }^{27}$ Lihat Adrianus Meliala, Menyingkap Kejahatan Kerah Putih (Jakarta: Sinar Harapan, 1992), hilm 21. 
berbàgai negara di dunia. ${ }^{28}$ Task Force on Money "Loundering di'Amerika Serikat telah melaporkan adanya "Narco dollars" (Perdagangan narkotik jutaan dollar). Dari laporan FATF tahun 1990, telah ditemukan sekitar US $\$ 122$ Miliar per tahun. ${ }^{29}$ Menurut Irene Luanadewi, sikap yang sama juga telah diperlihatkan oleh Prancis dan Swiss, tidak akan mempertahankan kembali asas kerahasiaan bank (bank secrecy), yang dikeramatkan selama ini, mereka akan memberi informasi sesuai tuntutan internasional. ${ }^{30}$

Bank intermediary memiliki kewenangan untuk melakukan pelaporan transaksi karensi, termasuk melakukan terobosan terhadap kerahasiaan para nasabah bank dengan melakukan pengidentifikasian para nasabah dan aktivitas dari nasabah dalam kaitannya dengan uang yang diperoleh masih menjadi perdebatan di Konggres Amerika. Baru setelah tragedi 11 September 2001, pemerintah Amerika Serikat melakukan peninjauan kembali terhadap nilai kerahasiaan Bank Sentral Federal (Federal Reserve Board) dan Departemen Perbankan di New York berusaha untuk melakukan komplain terhadap UU Kerahasiaan Bank (Bank Secrecy Act) melalui pengujian dan fungsi audit dan melaluj desiminasi dari prosedur dan petunjuk mengenai anti pencucian uang yang diatur oleh bank. Cara-cara monitoring dan pengawasan telah menyempumakan dengan meningkatkan upaya penyelidikan manajemen keuangan. Bagi Indonesia, kedudukan Bank Indonesia dapat dijadikan pusat pengawasan praktek pencucian uang yang dilakukan oleh bankbank lainnya.

Mulai 23 Agustus 2002, pemerintah Amerika Serikat mengeluarkan perintah untuk membekukan 219 organisasi atau golongan yang menjadi nasabah bank di Amerika. Tidak kurang dari 159 kelompok Islam Al-Qaedah atau Islamic Amy (NOI), Rabita Trust Abu Nidal, Al-Haramain Foundation (Bosnia-Somalia), Abu Sayaf Group. ${ }^{31}$ Abu Bakar Baasir tidak termasuk dalam executive orde № 13224. Tentu saja dikeluarkannya Surat Perintah Presiden itu sangat politis dalam kaitannya dengan berbagai peritiwa pembomoman di beberapa tempat, selain AS telah memperoleh keuntungan yang cukup banyak.

\section{Pengetahuan Keimigrasian}

Sebagaimana telah dikemukakan di atas bahwa globalisasi juga ditentukan oleh faktorfaktor idiologi, barang, jasa, teknologi, orang, uang, dan produksi, oleh karena itu diperlukan peraturan domestik untuk keperluan pengetahuan keimigrasian.

Karena itu, periunya perubahan paradigma baru terhadap UU No. 9 Tahun 1992 tentang Keimigrasian tidak bisa dihindarkan. Perlunya

${ }^{28}$ Informasi yang lebih detil baca Michael Levi. Money Londering and its Regulation (ANNALS AAPSS 582, July 2002), hlm 187.

${ }^{20}$ Peristiwa tersebut sebenarnya terkait dengan mafia-mafia Piza Connection yang melakukan pencucian uang US $\$ 600$ juta sekitar tahun 1984. Lihat R.M. Ikhsan, "Mencekal Pencucian Uang", uww.indomedia.com/ sripo/200220/2007 opini.

${ }^{30}$ Lihat juga Irena Luanadewi wuw.mweb.co.id.article 21 Mei 2001.

${ }^{31}$ Lihat Fact Sheet Office of the Coordinator for Counter Terrorism, Washington, DC, Office of the Coordinator For Counter Terrorism, 11 October 2002. 
perubahan paradigma baru mengenai UU Keimigrasian dipengaruhi oleh selain aspek globalisasi yang membawa implikasi terhadap kejahatan, di mana rentang batas geografis semakin kurang begitu mudah dikontrol oleh apa yang disebut kedaulatan negara, juga isu HAM dapat menimbulkan kegamangan bagi petugas penegak hukum, khususnya petugas imigrasi.

Dalam kaitannya dengan kompleksitas kejahatan transnasional, penataan ädministrasi pemberian visa terhadap warga negara asing (reciprocal principle), termasuk juga kemungkinan pemberian Visa Permanent Resident atau warga negara, bagi investor yang akan menetap di Indonesia. Belum lagi yang terkait dengan hak-hak warga negara yang telah lama tinggal di luar negeri, apakah. masih perlu memperlihatkan bukti kewarga negaraan"Rl (BKNRI). Tidak kalah pentingnya, adalah masalah bias Gender dalam persoalan kewarga negaraan.

Menurut Imam Santoso, pergeseran paradigma keimigrasian ditandai oleh Transnasional Organize Crime (TOC), yang terkait dengan OSP (Penyelundupan Obat , Senjata dan Pencucian Uang), juga semakin meningkatnya kecenderungan "Penyelundupan "manusia, anak dan wanita" People Smugling, termasuk Illegal Imigrant dan masalah gender, TKI dan terorisme..$^{32}$ Sisi lain yang amat penting adalah peranan polisi imigrasi. Situasi ini menjadi tidak mudah sebab jika polisi sebagai pintu gerbang pencegah dan penegakan hukum, tentu saja clean govern- ment, termasuk polisi yang bersih, jujur, komitmen dan setia terhadap hukum. Padahal disadari citra polisi sampai saat ini menjadi problem utama lemahnya penegakan hukum.

Suatu survey yang dilakukan oleh political and economic risk consultancy di Hongkong menyebutkan bahwa sistem hukum saat ini begitu parah di Indonesia, salah satu sebabnya peradilan dan polisinya terburuk di Asia. Indonesia (9.83), Thailand (7.96), Philipina dan China (7.78) dan India. Amerika Serikat, Australia, Singapura, Hongkong, dan Jepang tergolong negara-negara terbaik sistem peradilan dan polisinya. ${ }^{33}$

Ketentuan hukum dari UU No 15 Tahun 2002 selain terdapat kelemahan secara substantif mengenai prinsip-prinsip dasamya, juga belum dilengkapi dengan institusi pengawasan yang dapatmendorong efektivitas ketentuan hukum tersebut.

Terkait dengan gelombang pengungsi, dan imigran yang datang ke Indonesia, mengisyaratkan pemerintah $\mathrm{RI}$ dan juga negara-negara ASEAN untuk menerapkan prinsip-prinsip dasar pengungsi. Salah satu fungsi dari upaya meratifikasi Konvensi tahun 1951 mengenai status pengungsi dan sejenisnya antara lain, memiliki kepastian hukum bagaimana pemerintah memperiakukan pengungsi sama penting dengan persoalan hakhak asasi manusia. Karena itu, cara-cara memperlakukan mereka membela dan juga periindungan terhadap mereka. Ketidak pedulian negara dan pemerintah berada dalam situasi yang gamang, melainkan juga upaya untuk

32 imam Santoso, "Pergeseran Paradigma Keimigrasian", Majalah Informasi Keimigrasian: PINTU GERBANG, No 46 Thn. XIll 2002, him 8-9.

${ }^{33}$ Anton Tabah, Polri dalam Transisi Demokrasi (Jakarta: CV. Mitra Hardhasuma, 2002), hlm 54. 
'memperiolè hak-hak hukum mẹlälui UNHCR "akan mengalamín' hambatan.

Untuk memasukan kebijákan pengungsi ini, akan juga sekaligus negara-negara di ASEAN menunjukan kesadaran akan penting perbedaan antara subyek hukum, hukum hak asasi manusia, hukum pengungsi dan hukum humaniter yang secara substantif dan prosedur dapat membantu memungkinkan beban pengungsi dan mereka yang selama ini tertekan dan tidak mungkin dipaksa untuk dikembalikan ke negaranya. ${ }^{34}$ Dengan hadimya UNHCR di Jakarta, sebagai cabang organisasi PBB mestinya juga sekaligus adanya pengakuan atas konvensi, sehingga mekanisme hubungan akan terasa semakin lebih mudah dan komprehensif.

Dengan demikian, pemberantasan yang harus mulai dikerjasamakan yaitu selain perlu peningkatan adanya kerjasama ASEAN melalui multilateral Treaty se-ASEAN, juga perlu dilengkapi dengan adanya infra struktur hukum yang memadai terkait dengan peraturan hukum senjata api, pencucian uang, keimigrasian dan persoalan pengungsi.

\section{Simpulan}

Modus operandi kejahatan, yang secara strategis terlihat dari hubungan segitiga negara, maka penyelundupan narkotik, senjata dan sejenisnya serta pencucian uang jelas merupakan elemen-elemen pendukung kejahatan terorisme. Sebagaimana hubungan itu terlihat ketika, AS memberikan sanksi terhadap Myanmar dan Rwanda. Peran segitiga hubungan kejahatan antara negara sebagai terlihat di negara-negara lain, juga telah berlangsung di negara-negara ASEAN. Bukti-bukti kongkrit keterlibatan negara-negara lain, apakah sebagai pemasok, atau sekedar fasilitasi penyelundupan sungguh telah menjadi ancaman.

Karena itu, kerjasama multilateral bukan saja sekedar kewajiban hukum internasional, melainkan juga kebutuhan yang secara kongkrit perlu ditindak lanjuti oleh programprogram yang lebih komprehensif. Sejak tiga tahun terakhir, negara-negara ASEAN telah menyepakati akan perlunya peningkatan pemberantasan TOC melalui berbagai bentuk - joint communique, termasuk peningkatan pada pemberantasan kejahatan teror bom.

Akan tetapi, realisasi dari pemberantasan komprehensif negara-negara ASEAN terhadap elemen-elemen pendukung terpeliharanya kejahatan terorisme amat tergantung kepada parameter substansi dan prosedur hukum pada sistem hukum nasional masing-masing. Atas dasar situasi internal dan eksternal itulah, pemberantasan terorisme melalui penelusuran senjata, obat terlarang dan pencucian uang hanya akan berjalan efektif bilamana langkahlangkah penyempurnaan terhadap aturan hukum dan institusinya segera dibenahi. Juga penyelundupan manusia akan memberi kepastian hukum bagi pemerintah $\mathrm{R}$ l dengan

${ }^{34}$ Lihat Joan M. Fitzpatrick, Human Rights Protection for Refugees Asylum Seekers, and Internally Displaced Persons (New York: Transnational Publisher Inc., 2001), hlm 3. 
negara-negara ASEAN utamanya dalam mencari jalan keluar secara komprehensif. Penyempurnaan tersebut mencakup keimigrasian, pengawasan bea dan cukai, di pelabuhan-pelabuhan. Termasuk peninjauan kembali mengenai kebijakan pemberian travel document, bagi pengurusan visa sebelum seseorang masuk ke negara yang dituju (destination country).

\section{Daftar Pustaka}

Fitzpatrick, Joan M. Human Rights Protection for Refugees, Asylum Seekers, and Intemally Displaced Persons: A Guide to Intemational Mechanisms and Procedures, New York: Transnational Publisher Inc., 2001.

Ganor, Boaz. Defining Terrorism: Is One Mans Terrrorist Another Mans Freedom Fighter?. ICT. Executive Director. October $7^{\text {th }}, 2001$.

Hobbs, Dick. "Professional and Organized Crime in Britain" in Mike Maguire etc.(ed.), The Oxford Handbook of Criminology, Oxford: Clarendon Press, 1994.

Honwana, Joan \& Gay Lamb, Small arms proliferation and drug, trafficking in South Africa, South Africa: Centre for Conflict Resolution Cape Town, University of Cape Town, 1998.

Levi, Michael. Money Londering and Its Regulation, ANNALS AAPSS 582, July 2002.

Meliala; Adrianus. Menyingkap Kejahatan Kerah Putih, Jakarta : Sinar Harapan,
1992.

Mittelman, James H. \& Robert Johnston, in The Globalization Syndrome: Transformation \& Resistance, (New Jersey: Priceton University Press, 2000).

Moeljatno. KUHP, Yogyakarta: Bumi Aksara, 1982.

Rosenau, James N. Along The Domestic Foreign Frontier: Exploring Governance in a Turbulent World, Cambridge: Cambridge Studies in International Relations, Cambridge University Press, 1997.

Santoso, Imam. "Pergeseran Paradigma Keimigrasian", Majalah Informasi Keimigrasian: PINTU GERBANG, No 46 Thn. XIII 2002.

Sillar, Barbara H. Islam, Politics and Tradition in South Sulawesi, New York: Comell University Press, 1977.

Stem, Jessica. The Ultimate Terrorists, London: Havard University Press, 1999.

Tabah, Anton. Polri dalam Transisi Demokrasi, Jakarta: CV. Mitra Hardhasuma, 2002.

Thontowi, Jawahir. Hukum Internasional di Indonesia: Dinamika dan Implementasinya Dalam Beberapa Kasus Kemanusiaan, Yogyakarta: Madyan Press, 2002.

Bea dan Cukai Surabaya Gagalkan Penyelundupan Senjata Api, www.kompas.com/kompas-cetakl 0207/0207/03daerah/beak/19htm.

"Dinas Penerangan Polri", www.tempo.co.id/ 
harian/55/2,1,14,id.html.

Fact Sheet Office of the Coordinator for Counter Terrorism, Washington, DC, Office of the Coordinator For Counter Terrorism, 11 October 2002. Harian Kedaulatan Rakyat, 15 Agustus 2002.

Harian Republika, 12 Juli 2002.

Luanadewi, Irena. www.mweb.co.id.article 21 Mei 2001.

Laporan Dinas Penerangan Polri, dalam www.tempo.co.id/harian $/ 551$ $\underline{2,1,14, \text { id.html }}$
Republika on Line. Selasa 9 Juli 2002.

R.M. Ikhsan, Mencekal Pencucian Uang, www.indomedia.com/sripo/2002 201 2007 opini.

Tempo Interaktif, 8 Agustus 2002.

"Thailand Selidiki Penyelundupan Senjata ke Aceh", www.tempointeraktif, 15 Mei 2001.

Yusario, Philip. "Transnational Organizer Crime. Isu dan Permasalahannya", dalam Analisa CSIS. No.Th.XXXI. Tahun 2002. 